\title{
Application of Fuzzy Logic in Prediction of Traffic Accidents
}

\author{
Dr. Elda Maraj' ${ }^{1}$ and Prof.(Dr) Shkelqim Kuka ${ }^{2}$ \\ ${ }^{1}$ Department of Mathematic Engineering, Mathematical Engineering and Physics Engineering Faculty, Polytechnic \\ University of Tirana, Tirana, Albania \\ ${ }^{2}$ Department of Mathematic Engineering, Mathematical Engineering and Physics Engineering Faculty, Polytechnic
} University of Tirana, Tirana, Albania

Correspondence should be addressed to Elda Maraj; e.maraj@fimif.edu.al

Copyright () 2022 Elda Maraj et al. This is an open-access article distributed under the Creative Commons Attribution License, which permits unrestricted use, distribution, and reproduction in any medium, provided the original work is properly cited.

\begin{abstract}
Prediction of traffic accidents has an important meaning in improving of road safety. Models of traffic accidents prediction can help for finding accident causes and to reduce the number of accidents. The purpose of this paper is to build a fuzzy logic model for prediction of traffic accidents in Albania. In this model are used six input parameters: annual average daily traffic (AADT), road width ( $\mathrm{rw}$ ), speed ( $\mathrm{sp}$ ) defined as the distance per unit of time, number of minor access (ma) along the street over the length of the street in kilometers, road surface condition as percentage $(\mathrm{pm})$, and the percentile of sign per kilometers of road (sj). The output of the model is the annual all accidents (AAA) that is defined as the number of all accidents occurring on the road in a defined time interval of a day per kilometer length of road.

This model is applied for seven roads in Albania. The results are discussed and taken the main conclusions of this paper. Here fuzzy logic toolbox of MATLAB is used.
\end{abstract}

KEYWORDS- Fuzzy logic toolbox, Traffic accidents, Prediction model

\section{INTRODUCTION}

Accidents cause injuries, death and material damage over the world creating many social and economic problems. In this paper, a fuzzy logic model is built to predict the accidents in Albania. Fuzzy logic model is proved to be suitable to deal uncertainty phenomena. Many factors such as traffic, people and environmental conditions cause accidents. Some of these factors may be static (geometry of the road) and some others may be dynamic (traffic). The main purpose of this paper is to show the environmental factors of the traffic accidents. The most effective factors are presented as the "input variables" of the fuzzy logic model. Road and traffic conditions are two factors that have a greater impact on traffic accidents. By studying these factors, the number of accidents may be reduced [1].

Driss et al. [2] solved the traffic accidents problem using fuzzy logic who defined the degree of exposure to road accident's risk by using traffic accident prediction system based on fuzzy logic.

Wahaballa et al. [3] used multiple regression analysis in their study traffic accident analysis and modeling for upper Egypt rural roads. They defined the most influential variables on traffic accidents. Their results showed that the percentage of accidents is inversely related with the width of the road and is directly related with the number of entrances to the road, and percentage of trucks.

Rokade et al. [4] by using multiple linear regression, built an accident prediction model. The input variables of the model were traffic volume, lighting conditions, speed, road shoulder width, road cross section dimensions, traffic signals and traffic signs. The number of accidents was the output of their model. Their model gave good results.

Rengarasu et al. [5] analyzed the seasonal changes on vehicle collisions on a rural two lane road and effects of road geometry. By using Poisson - regression models, they built a segmented accident database based on traffic accident analysis system.

Meng et al. [6] used fuzzy logic model for studying road accident frequencies with different traffic and road conditions. They selected AADT and traffic load calculated by volume/capacity as the prominent influence factors by the model.

Ghanbari et al. [7] created a decision support system to choose the kind of intelligent transportation system for the highways by using fuzzy logic model. They applied the model for two highways. Their model gave good results.

Zaied et al. [8] solved the problem of accidents at intersection by using fuzzy logic. They built a fuzzy logic traffic system for isolated signalized intersections and which is able for changing signal timings according to situation level.

In this paper are used six input parameters: annual average daily traffic (AADT), road width (rw), speed (sp) defined as the distance per unit of time, number of minor access (ma) along the street over the length of the street in kilometers, road surface condition as percentage (pm), and the percentile of sign per kilometers of road (sj). The output of the model is the annual all accidents (AAA) that is defined as the number of all accidents occurring on the road in a defined time interval of a day per kilometer length of road [1].

The built model is applied based on the data collected for one year (2018) in seven roads of Albania such as Elbasan Librazhd road, Plepa - Rrogozhine road, Lushnje - Fier road, Pogradec - Korce road, Vore - Fushe Kruje road, Tirane - Kashar road, and Kamez - Fushe Kruje road.

\section{FUZZY LOGIC}

Fuzzy logic and fuzzy sets were developed for representing, changing, and applying uncertain information and for 
developing a system to deal with uncertainty and imprecision in real-world applications [9]. Fuzzy logic systems secure an effective and accurate method to describe human perceptions. The theory of fuzzy logic provides a mathematical power to catch the uncertainties such as thinking and reasoning [10].

Some of the basic characteristics of fuzzy logic are given as follow [11]:

- Exact reasoning is considered as a limiting case of approximate reasoning.

- Knowledge is explained a collection of elastic.

- Inference is considered as a process of spread of elastic constraints.

- Any logical system may be fuzzified. Moreover, there are also two main characteristics of fuzzy systems:

- $\quad$ Fuzzy systems are convenient for uncertain or approximate reasoning.

- $\quad$ Fuzzy logic permits decision making with estimated values by incomplete or uncertain information.

There are two fuzzy models used in practice such as Mamdani fuzzy model and Sugeno fuzzy model. In this paper is used Mamdani fuzzy model.

\section{A. Mamdani Fuzzy Model}

The Mamdani fuzzy model use the linguistic variables for describing the process states and use these variables as input for controlling rules. The terms of the linguistic variables are fuzzy sets with given shape. The most used shapes are the trapezoidal or triangular fuzzy set but other shapes are possible. Mamdani Fuzzy model can be formulated in five steps as follow [12];

- Fuzzify input: define all fuzzy statements in the antecedent and get a degree of membership between 0 and 1.

- Apply fuzzy operator to multiple part antecedents: use the fuzzy logic operators and reselect the antecedent to a single number between 0 and 1 .

- Apply implication method: use the degree of support for the rule for shaping the output fuzzy set.

- $\quad$ Aggregate all Outputs: combine all the fuzzy sets that show the outputs of each rule.

- Defuzzify: defuzzify the aggregate output fuzzy set in a single number.

\section{STUDY AREA}

Albania is a parliamentary constitutional republic that is located in southeast Europe. It has an area of $28,748 \mathrm{~km} 2$. Its northernmost point is Vërmosh, the southernmost is Konispol, the westernmost point is Sazan, and the easternmost point is Vërnik . The highest point is Mount Korab with a height of $2,753 \mathrm{~m}$. Albania has continental climate with four distinct seasons. Its population is very young compared to the European Union and the region of southeast Europe. The official language of the country is Albanian.

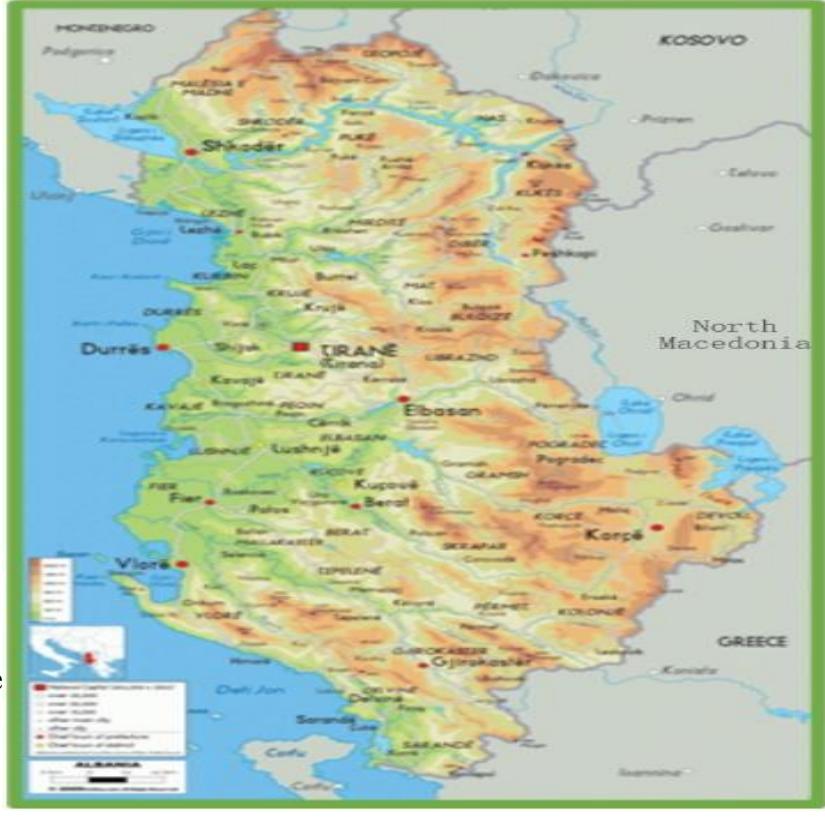

Figure 1: Physical map of Albania

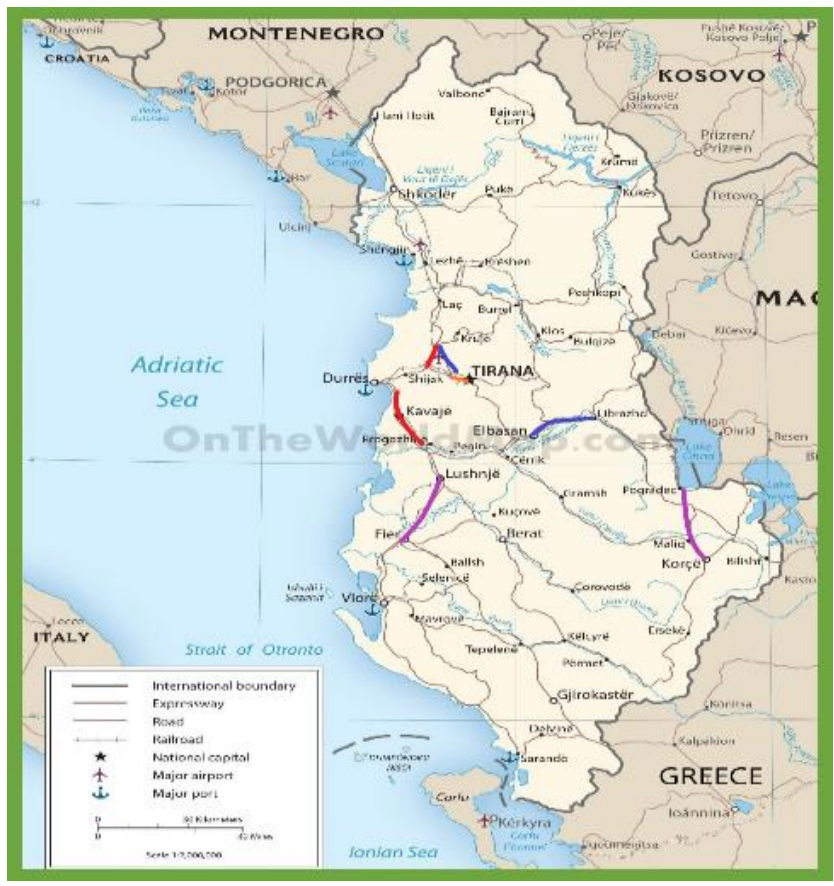

Figure 2: A sketch of roads in study

In this paper we have studied the prediction of road accidents based on the data collected for one year (2018) in seven roads of Albania such as Elbasan - Librazhd road, Plepa - Rrogozhine road , Lushnje - Fier road, Pogradec Korce road, Vore - Fushe Kruje road, Tirane - Kashar road, and Kamez - Fushe Kruje road.

\section{DESIGN STEPS}

\section{A. Fuzzy Inference System}

The Figure 3 shows the Mamdani FIS model that we have used for our system. 


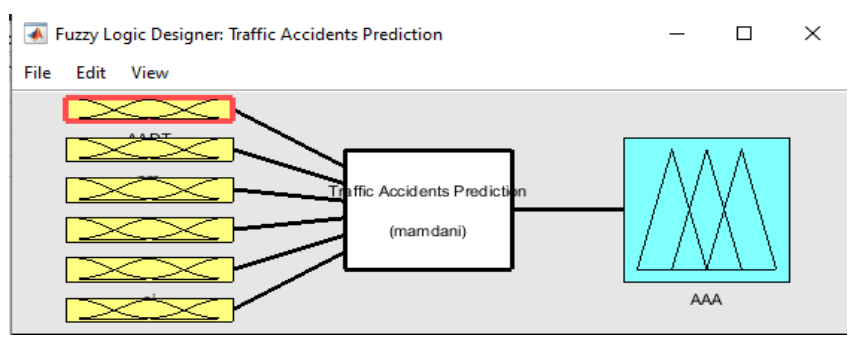

Figure 3: Mamdani FIS Model

Furthermore, the above figure shows the inputs and output of our system. They are explained below in detail.

\section{B. Input}

The input variables of our model are: annual average daily traffic (AADT), road width (rw), speed (sp), number of minor access (ma) along the street over the length of the street in kilometers, road surface condition as percentage (pm), and the percentile of sign per kilometers of road (sj). Membership functions of inputs are shown as Fig.4, Fig.5, Fig.6, Fig.7, Fig.8 and Fig.9 [1].

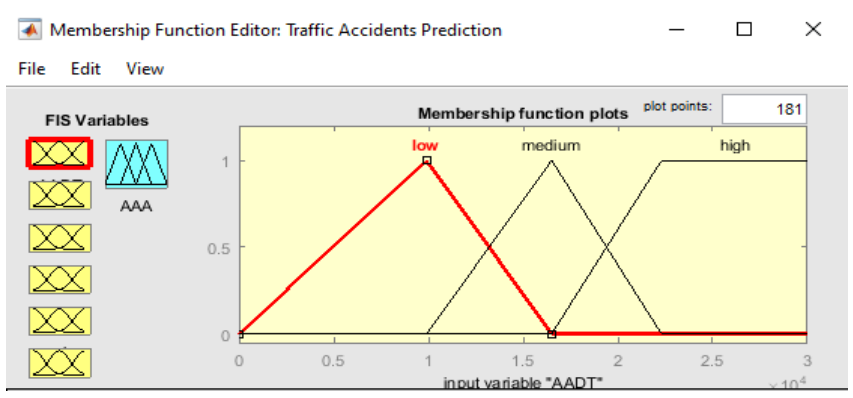

Figure 4: Membership Function of Input Variable AADT

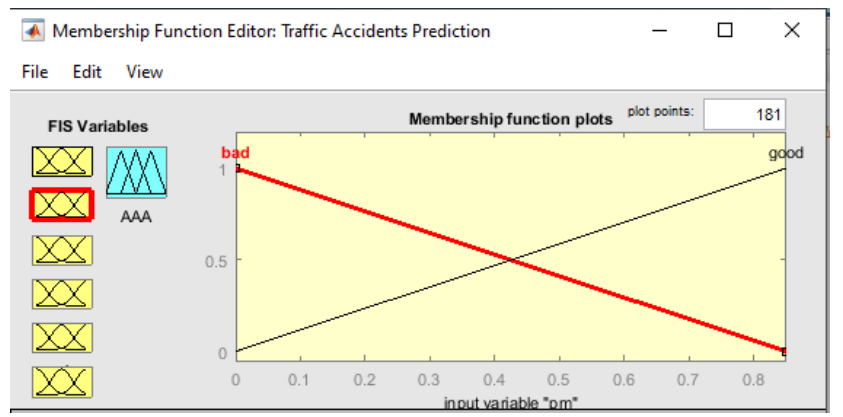

Figure 5: Membership Function of Input Variable "pm"

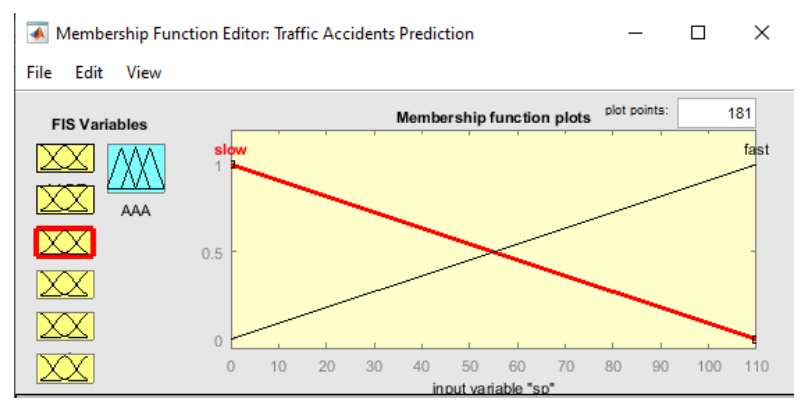

Figure 6: Membership Function of Input Variable "sp"

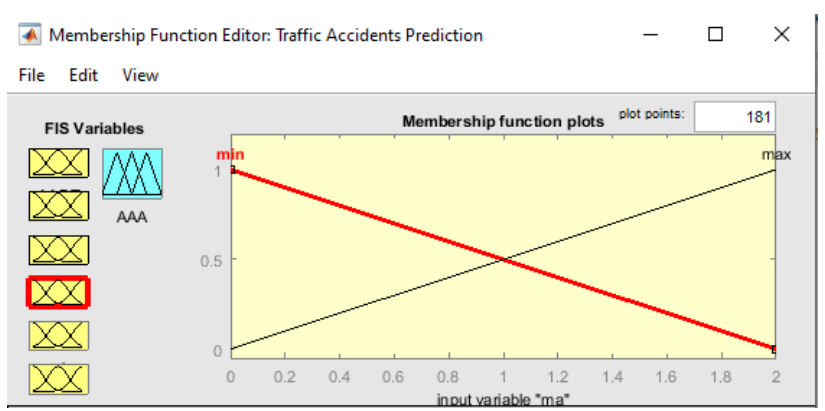

Figure 7: Membership Function of Input Variable "ma"

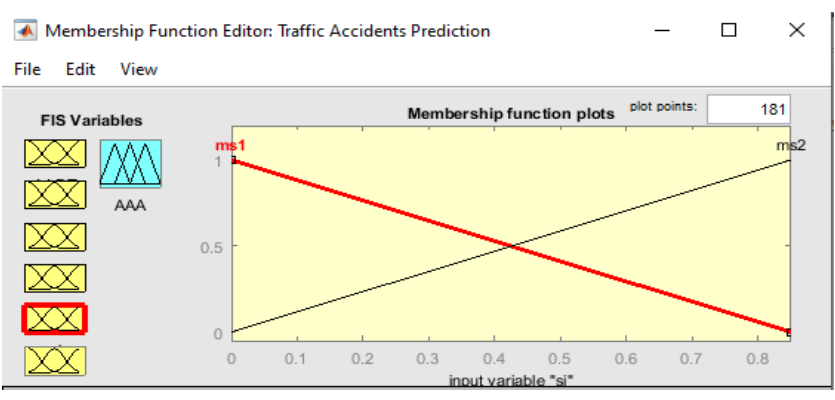

Figure 8: Membership Function of Input Variable “sj”

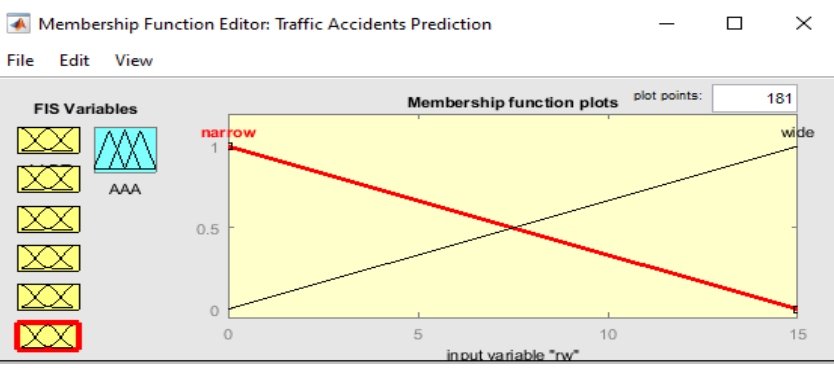

Figure 9: Membership Function of Input Variable "rw"

\section{Output}

Figure 10 shows the output of our designed system, the annual all accidents (AAA) that is defined as the number of all accidents occurring on the road in a defined time interval of a day per kilometer length of road [1].

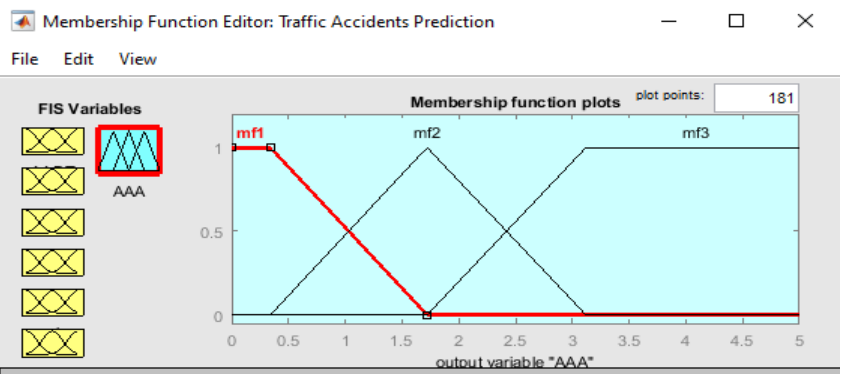

Figure 10: Membership Function of Output Variable AAA.

\section{Design Rules}

Figure 11 shows the Rule Viewer that represents all inputs, outputs, and IF-THEN rules of our model. The following figure shows the case when $\mathrm{AADT}=15000, \mathrm{pm}=0.425$, $\mathrm{sp}=55, \mathrm{ma}=1, \mathrm{sj}=0.425, \mathrm{rw}=7.5$. For these values of the input variables the fuzzy model predicts the output variable $\mathrm{AAA}=2.5$. 


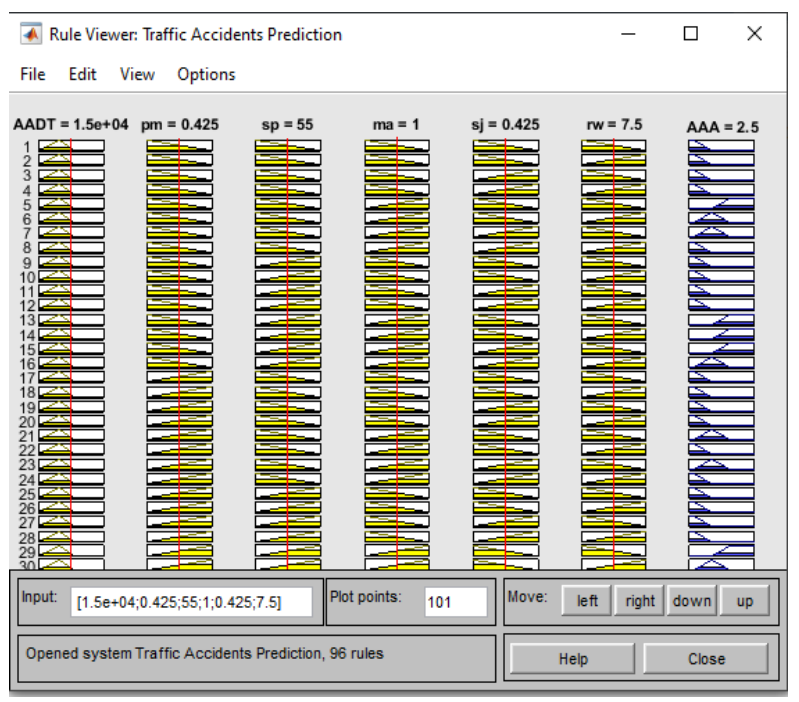

Figure 11: Rule Viewer

Figure 12 shows the Surface Viewer. This figure shows the output variable AAA and accuracy of fuzzy rules with respect to various combinations of input variables. In this case are presented input variables rw and sp.
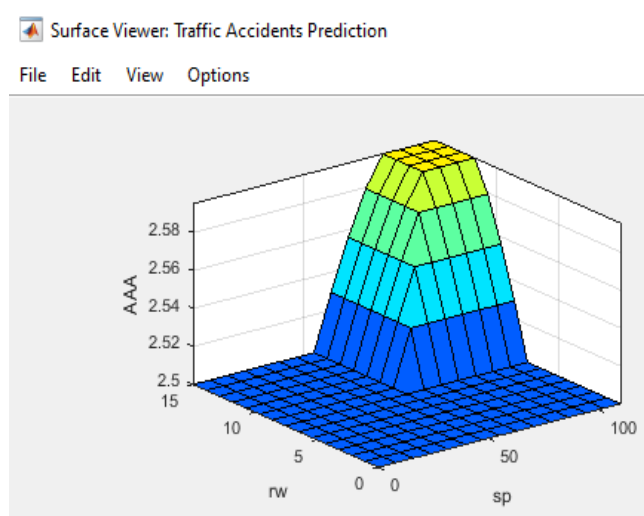

Figure 12: Surface Viewer

\section{RESULTS}

In this study, to construct fuzzy model are used: annual average daily traffic (AADT), road width (rw), speed (sp), number of minor access (ma) along the street over the length of the street in kilometers, road surface condition as percentage $(\mathrm{pm})$, the percentile of sign per kilometers of road (sj), and the annual all accidents (AAA). These data are taken for one year (2018) in seven roads of Albania such as Elbasan - Librazhd road, Plepa - Rrogozhine road, Lushnje - Fier road, Pogradec - Korce road, Vore - Fushe Kruje road, Tirane - Kashar road, and Kamez - Fushe Kruje road, and are presented respectively in Table 1, Table 2, Table 3, Table 4, Table 5, Table 6 and Table 7. The Fuzzy model was constructed according to Mamdani type. To develop the Mamdani FIS model are used $3 \times 2 \times 2 \times 2 \times 2 \times 2=96$ mechanical rules.
Table 1: Elbasan - Librazhd Road

\begin{tabular}{|l|l|}
\hline Year & 2018 \\
\hline AADT & 24.1 \\
\hline $\mathrm{rw}(\mathrm{m})$ & 3.46 \\
\hline $\mathrm{sp}(\mathrm{km} / \mathrm{h})$ & 60 \\
\hline $\mathrm{ma}$ & 1.24 \\
\hline $\mathrm{pm}$ & 0.85 \\
\hline $\mathrm{sj}$ & 0.85 \\
\hline AAA Predicted & 1.55 \\
\hline AAA Observed & 0.226 \\
\hline Absolute error & 1.32 \\
\hline
\end{tabular}

Table 2: Plepa - Rrogozhine Road

\begin{tabular}{|l|l|}
\hline Year & 2018 \\
AADT & 315.6 \\
\hline rw $(\mathrm{m})$ & 3.5 \\
\hline $\mathrm{sp}(\mathrm{km} / \mathrm{h})$ & 100 \\
\hline $\mathrm{ma}$ & 1.63 \\
\hline $\mathrm{pm}$ & 0.85 \\
\hline $\mathrm{sj}$ & 0.85 \\
\hline AAA Predicted & 1.54 \\
\hline AAA Observed & 0.074 \\
\hline Absolute error & 1.47 \\
\hline
\end{tabular}

Table 3: Lushnje - Fier Road

\begin{tabular}{|l|l|}
\hline Year & 2018 \\
\hline AADT & 199.8 \\
\hline $\mathrm{rw}(\mathrm{m})$ & 3.44 \\
\hline $\mathrm{sp}(\mathrm{km} / \mathrm{h})$ & 90 \\
\hline $\mathrm{ma}$ & 1.5 \\
\hline $\mathrm{pm}$ & 0.85 \\
\hline $\mathrm{sj}$ & 0.85 \\
\hline AAA Predicted & 1.54 \\
\hline AAA Observed & 0.177 \\
\hline Absolute error & 1.36 \\
\hline
\end{tabular}

Table 4: Pogradec - Korce Road

\begin{tabular}{|l|l|}
\hline Year & 2018 \\
\hline AADT & 6.4 \\
\hline $\mathrm{rw}(\mathrm{m})$ & 3.56 \\
\hline $\mathrm{sp}(\mathrm{km} / \mathrm{h})$ & 50 \\
\hline $\mathrm{ma}$ & 2.24 \\
\hline $\mathrm{pm}$ & 0.85 \\
\hline $\mathrm{sj}$ & 0.85 \\
\hline AAA Predicted & 1.55 \\
\hline AAA Observed & 0.273 \\
\hline Absolute error & 1.28 \\
\hline
\end{tabular}


Table 5: Vore - Fushe Kruje Road

\begin{tabular}{|l|l|}
\hline Year & 2018 \\
\hline AADT & 11.1 \\
\hline $\mathrm{rw}(\mathrm{m})$ & 3.37 \\
\hline $\mathrm{sp}(\mathrm{km} / \mathrm{h})$ & 80 \\
\hline $\mathrm{ma}$ & 2.43 \\
\hline $\mathrm{pm}$ & 0.85 \\
\hline $\mathrm{sj}$ & 0.85 \\
\hline AAA Predicted & 1.55 \\
\hline AAA Observed & 0.27 \\
\hline Absolute error & 1.28 \\
\hline
\end{tabular}

Table 6: Tirane - Kashar Road

\begin{tabular}{|l|l|}
\hline Year & 2018 \\
\hline AADT & 217 \\
\hline $\mathrm{rw}(\mathrm{m})$ & 3.56 \\
\hline $\mathrm{sp}(\mathrm{km} / \mathrm{h})$ & 50 \\
\hline $\mathrm{ma}$ & 2.66 \\
\hline $\mathrm{pm}$ & 0.85 \\
\hline $\mathrm{sj}$ & 0.85 \\
\hline AAA Predicted & 1.54 \\
\hline AAA Observed & 0.61 \\
\hline Absolute error & 0.93 \\
\hline
\end{tabular}

Table 7: Kamez - Fushe Kruje Road

\begin{tabular}{|l|l|}
\hline Year & 2018 \\
\hline AADT & 76.1 \\
\hline rw $(\mathrm{m})$ & 3.49 \\
\hline $\mathrm{sp}(\mathrm{km} / \mathrm{h})$ & 60 \\
\hline $\mathrm{ma}$ & 2.62 \\
\hline $\mathrm{pm}$ & 0.85 \\
\hline $\mathrm{sj}$ & 0.85 \\
\hline AAA Predicted & 1.55 \\
\hline AAA Observed & 0.314 \\
\hline Absolute error & 1.24 \\
\hline
\end{tabular}

\section{CONCLUSIONS}

In this paper is presented a model for the prediction of traffic accidents that can be used effectively for transport management, planning, and safety assessment at any time. The aim of the analysis is to build an accident prediction model and consideration of factors that contribute to the occurrence of traffic accidents using data for Elbasan Librazhd road, Plepa - Rrogozhine road, Lushnje - Fier road, Pogradec - Korce road, Vore - Fushe Kruje road, Tirane - Kashar road, and Kamez - Fushe Kruje road.

In this study is applied fuzzy inference system based in traffic accident prediction algorithm. This model was built using AADT, rw, ma, sj, sp and pm as input variables and AAA as an output variable. The factors that affect in the increase of safety and the reduction of the phenomenon of traffic accidents based on the model that have built, being ranked according to their importance are: ma (It is necessary to fully control the side entrances), AADT (It is necessary to reduce annual average daily traffic), rw (It is necessary to increase the road width), sp (It is necessary to reduce the speed on the road), sj (It is necessary to increase the efficiency of traffic signs), and pm (It is necessary to repair defects of the road surface).

\section{CONFLICTS OF INTEREST}

The authors declare that they have no conflicts of interest.

\section{ACKNOWLEDGMENT}

Authors acknowledge the General Director of Road Policy in Albania, and Albanian Road Authority for supporting with real data.

\section{REFERENCES}

[1] Mohammed Gaber, Amor Mohamed Wahaballa, Ayman Mahmoud Othman, Aboelkasim Diab, "Traffic Accidents Prediction Model Using Fuzzy Logic: Aswan Desert Road Case Study", Journal of Engineering Sciences, Assiut University, Faculty of Engineering, Volume 45, NO. 1 January 2017, PP.28-44.

[2] Driss, M., Saint-Gerand, T., Bensaid, A., Benabdeli, K., \& Hamadouche, M. A. (2013, May). A fuzzy logic model for identifying spatial degrees of exposure to the risk of road accidents (Case study of the Wilaya of Mascara, Northwest of Algeria). In Advanced Logistics and Transport (ICALT), 2013 International Conference on (pp. 69-74). IEEE.

[3] Wahaballa, M., A., Othman,M.,A., and Ahmed,H., (2006), Traffic Accident Analysis \&Modeling for Upper Egypt Rural Roads, Mansoura engineering journal.

[4] Rokade, S., Singh, K., Katiyar, S. K., \& Gupta, S. (2010). Development of accident prediction model. International Journal of Advanced Engineering Technology, 1(3), 25-40.

[5] RENGARASU, T. M., HAGIWARA, T., \& HIRASAWA, M. (2007). Effects of road geometry and season on head-on and single-vehicle collisions on rural two lane roads in Hokkaido, Japan. In Proceedings of the Eastern Asia Society for Transportation Studies (Vol. 2007, No. 0, pp. 2860-2872). Eastern Asia Society for Transportation Studies.

[6] MENG, X. H., ZHENG, L., \& QIN, G. M. (2009). Traffic Accidents Prediction and Prominent Influencing Factors Analysis Based on Fuzzy Logic [J]. Journal of Transportation Systems Engineering and Information Technology, 2, 015.

[7] Ghanbari, M., Mehr, A. G., \& Nehzat, H. Introducing an Intelligent Transportation System Decision Support Model for the Highways in Iran Based on Fuzzy Logic.

[8] Zaied, A. N. H., \& Al Othman, W. (2011). Development of a fuzzy logic traffic system for isolated signalized intersections in the State of Kuwait. Expert Systems with Applications, 38 (8), 9434-9441.

[9] Lin, J. W.; Hwang, M. I.; and Becker, J. D. (2003). “A fuzzy neural network for assessing the risk of fraudulent financial reporting", Managerial Auditing Journal 18/8 pp 657-665.

[10] Walid, A. H. (2005). "Accuracy Enhancement of Integrated MEMS-IMU/GPS Systems for Land Vehicular Navigation Applications", Ph. D. Thesis, Department of Geomatics Engıneering, Unıversity of Calgary, Calgary, Alberta, Canada.

[11] Zadeh, L. (1984). "Making Computers Think Like People", IEEE Spectrum, Vol.(7), pp 26-32.

[12] S. N. Sivanandam, S. Sumathi and S. N. Deepa, "Introduction to Fuzzy Logic using MATLAB”, 2006-2007, pp. 118 - 128. 